\title{
In Defence of the Laws of War
}

\author{
Esther D. Reed
}

This essay warns that Nigel Biggar's permissive reading of the classic, theological just war tradition is problematic especially when combined with his highly contextual approach to the United Nations Charter and laws of war. Two points are made: (1) As compared to Augustine's grappling with the disordered loves of the Roman empire - including 'foreign iniquity' as an excuse for military action, the animus dominandi, and wars of a kind that generate more war - In Defence of War lacks a political realism robust enough to defend against leaving the laws of war in the hands of the most powerful nations. (2) As compared to Augustine's engagement with why and how secular law must constitute the conditions for peaceable and ordered co-existence, In Defence of War fails to incorporate into its just war reasoning a defence of the legal regime necessary for the protection of international peace and security.

There is much in Nigel Biggar's In Defence of War that I welcome and affirm, notably the need for those who stand within the classic, theologically Christian, narrowly penal, judicial tradition of just-war moral reasoning to refine that tradition and think with it afresh today. With Biggar, I want to defend and develop this tradition not only as viable but needed in our present-day context, despite the plethora of challenges to the effect that it is exhausted and unfit for the complexities of socalled fourth- and fifth generation warfare, and more.

To this end, it is necessary to be clear (as Biggar is crystal clear) that not all just-war reasoning is the same. Modern liberal versions look very different to the earlier tradition that runs from Ambrose and Augustine through Aquinas and beyond. It is necessary to have the debates that Biggar frames about why positive law is subject to a higher natural law, why retribution is not always contrary to the evangelical imperative to love, the difference between accepting that soldiers will sometimes have to kill and intending or wanting to kill, the complexities entailed in thinking with the classic just war tradition about recent and present-day conflicts, and more. In all these respects, I welcome In Defence of War as a significant contribution to this tradition and its refinement in the present-day.

Yet questions must be asked about aspects of the book. I select two for comment:

1. How does the realism that pervades In Defence of War compare to the political rhetoric of the City of God? 
2. Does Biggar's contextualism with respect to interpretation of the laws of war lean too far toward flexibility in ways that undermine the legal regime in place to protect international peace and security?

My differences with Biggar are those of the emphasis and interpretation of the early Christian just war tradition, not principle. But these emphases matter if Christian ethics and political theology today is to be sufficiently realist, that is, concerned with the restraint of wrong-doing and securing of things helpful to this life.

\section{Reading In Defence of War and The City of God Side-by-Side}

Augustine is, as Biggar affirms, 'the leading patriarch of Christian just war doctrine' (p. 61). More is required in just-war reasoning today, however, than thinking with merely the passages most familiar to expounders of the just war tradition — namely, a few chapters from Augustine's The City of God and handful of letters in reply to Faustus the Manichaean and Marcellinus of Carthage, Aquinas' answer to the question of war in four articles, and familiar writings by Francisca de Vitoria, Alberico Gentili, and Francisco Suarez. ${ }^{1}$ My point is not that Biggar advocates this kind of reductionism but that just-war reasoning requires broader-based engagement with Christian tradition than is familiar in just-war reasoning today, including what Augustine says about the politics and law of the Roman Empire. Time and again, Augustine holds up a mirror to the Empire to see where (at least partially) virtuous intent falls into excess, aggression, illegality and yet more war, and/or when it results in governance for those governed, taking counsel (L. consulere) with the elders, and seeking after just peace. We need Augustine's alertness to when ordinate concerns (e.g., for present purposes, national security, the overcoming of wrong-doing and protection of the innocent) become vulnerable to degeneration into illegality, violence, the lust for domination, and other vices. Inattention to these aspects of the tradition risks present-day conclusions that are off-balance because incomplete.

\section{Rhetorical 'Tools and Knives'}

While attention has been paid to the rhetorical aspects of Confessions, the sermons and On Christian Doctrine, relatively few scholars have examined the political

\footnotetext{
${ }^{1}$ I take this list from Larry May, Eric Rovie and Steve Viner, The Morality of War: Classical and Contemporary Readings (Cambridge: Pearson Publishing, 2005) as indicative of familiar perspectives on the major texts of the classic just-war tradition.

${ }^{2}$ Phrase from Alain Badiou, Polemics (Verso, 2006), p.35.
} 
rhetoric in the City of God. John von Heyking's Augustine and Politics as Longing in the World is a noted exception that examines how Augustine heaps scorn on the pretensions of Rome's leaders whilst analyzing simultaneously how the quest for glory that dominated Roman life decomposes into inordinate passions and warning believers against supposing that Christianity 'has solved the problem of reconciling wisdom and power'. ${ }^{3}$ So, for instance, Heyking draws attention to how some of Augustine's most extreme claims about the moral destitution of the Romans are made in relation to the glory they loved ardently:

They chose to live for it, and they did not hesitate to die for it ... It was, therefore, this avidity for praise and passion for glory that accomplished so many wonderous things; things which were doubtless praiseworthy and glorious in the estimation of men. ${ }^{4}$

'[B]ecause they did not love glory for the sake of justice, but seem rather to have loved justice for the sake of glory, they subsequently broke the treaty of peace which they had made'. ${ }^{5}$ The Roman quest for glory was not always reprehensible. But Augustine holds up a mirror to the empire to see where (at least partially) virtuous intent falls into excess, aggression, illegality and yet more war.

Following Augustine's lead, the challenge today is not to denounce concerns for security and the protection of nationals per se, or to exclude the debate about humanitarian intervention as falling outside the just-war tradition - this would be perverse - but to discern whether and/or when these (at least partially) virtuous endeavors tip into vice, notably, unlawfulness, the relaxation and expansion of longestablished rules to delimit the use of armed force, inattention to the due process of law, the prospect of perpetual war, and sometimes a mask for murder.

Now the prominence of this desire in the character of the Romans is shown by the fact that the temples of the gods which they established in the closest proximity to one another were those of Virtue and Honour (for they took the gifts of God to be gods themselves). ${ }^{6}$

Today, we do not build temples to Virtue and Honour but elevate certain concepts and/or principles, such as collective security and democracy, to the status of quasireligious symbols, the observance of which can substitute for government for the

\footnotetext{
${ }^{3}$ John von Heyking, Augustine and Politics as Longing in the World (University of Missouri Press, 2001), p.18.

${ }^{4}$ Augustine, The City of God against the Pagans, Ed., R. W. Dyson, (Cambridge University Press, 1998, hereafter $C G$ ), V.12, p. 207.

${ }^{5} C G, \mathrm{~V}, 22, \mathrm{p} .229$.

${ }^{6} C G, \mathrm{~V}, 12, \mathrm{p} .210$.
} 
international common good. As the miser forsakes justice out of his love for gold, the fault lies not with the gold but with the person if love of the gold is not properly subordinated to love of other goods. ${ }^{7}$

Books IV and V of The City of God - in which Augustine considers most clearly the false gods worshipped by Rome during the period when God permitted the vast expansion and dominance of Empire - yield questions that also retain their relevance: Is peace preferable to war? Is victory sought for its own sake? Does 'foreign iniquity' provide an excuse for military action?

He prays ill, therefore, who desires to have someone to hate or to fear in order to have someone to conquer. ... For we see that Foreign Iniquity has contributed much to the increase in the breadth of the empire, by making foreigners so unjust that they become peoples against whom just wars may be waged and the empire thereby enlarged. ${ }^{8}$

Just-war reasoning today needs to hold questions about the 'right cause', 'right authority' and 'right intention' of armed conflict together with an Augustine-like knack for exposing the vices to which great political powers are vulnerable.

\section{On the Purpose of Law}

Relatedly, just-war reasoning needs due attention to the purpose of law. Augustine was not starry-eyed in his dealings with the law of empire. As bishop, he approached civil officials to intercede on behalf of debtors, got involved in day-to-day legal conflicts, commented on the duties of judges and how well they performed their role, ${ }^{9}$ intervened according to the custom of the day to ask judges to mitigate the sentence and to punish more leniently than the laws commanded, ${ }^{10}$ offered suggestions about how mediation might take place between disputing claimants, ${ }^{11}$ as well as helping Christians settle disputes amongst themselves about the sale of goods, disputes over land, standards of evidence, and more. ${ }^{12}$ Pilgrims journeying toward the Heavenly City need the peace and security of secular order and so must obey the laws of the earthly city whereby the things necessary for the support of this mortal life are administered. He was clear that all the activities of civic life are enveloped in shadow

\footnotetext{
${ }^{7} C G, \mathrm{XV}, 22, \mathrm{p} .679$.

${ }^{8} C G, \mathrm{IV}, 15, \mathrm{p} .162$.

${ }^{9}$ See Eva-Maria Kuhn, 'Justice Applied by the Episcopal Arbitrator: Augustine and the Implementation of Divine Justice', Ethics \& Politics, IX, 2007, 2, pp. 71-104, at 81-82, re: Augustine, Confessions VI, 8, 13; Ep. 134 re: Letter to Apringius Ep. 134 (CSEL 44, 84-88).

${ }^{10}$ Kuhn, 'Justice Applied', p.86 re: Letter to Marcellinus, Ep. 139, 2 (CSEL 44, 151).

${ }^{11}$ Augustine, Exposition on Psalm 72, 3.

${ }^{12}$ Kuhn, 'Justice Applied', p.92 re: Augustine, Letter 8.1.3-4 (CSEL 88, 41).
} 
or darkness in the light of Civitas Dei. ${ }^{13}$ Nevertheless, laws properly enacted are for the protection of societies not the furtherance of political influence. The purpose of law is to establish and maintain 'the tranquility of order'. ${ }^{14}$

\section{Politics East of Eden}

This brings us to an oft-neglected aspect of Augustine's writings, namely, the demand of the political. Augustine is often held to have had such a low view of human law and politics after the fall that his theology of law is preoccupied with restraining disorder and lawlessness not the directing of societies toward peaceable living. His highlighting of the 'sense of the tragic' with respect to human nature means that he eschews the kind of utopian ideologies that were so destructive in the twentieth century'. ${ }^{15}$ There is a sense, however, in which, for Augustine, the natural and educative purpose of politics remains. In Eden, says Augustine, politics is the proper activity of rational beings seeking after their perfection: 'creatures are instructed and learn, fields are cultivated, societies are governed, the arts are practiced, and other activities go on both in heavenly society and in this mortal society on earth'. ${ }^{16}$ The essence of politics proper is the bond of concord that unites Edenic human being as social:

God therefore created only one single man: not, certainly, that he might be alone and bereft of human society, but that, by this means, the unity of society and the bond of concord might be commended to him more forcefully .... ${ }^{17}$

Natural providence provides not only that humans live within the affection of kinship but also socially and politically. Voluntary providence, that is, which operates in the activities of humans (and angels) such that they may administer societies, practice the arts of healing, technology, education, and such like, under God.

The contradiction of earthly government is that it is both instituted by God for some kind of ordering toward common good and imbued with violence from its birth. Augustine's mournful telling of the history of Rome implies frequently that law's violence is preferable to disorder and as a way of countering the manifestations of fallen human nature. Secular law must constitute the conditions for peaceable and

\footnotetext{
${ }^{13}$ See John M. Rist, Augustine: Ancient Thought Baptized (Cambridge: CUP, 1996), p.215.

${ }^{14} C G$, XIX, 13, p.938.

${ }^{15}$ Thomas W. Smith, 'The Glory and Tragedy of Politics' in John Doody, et al., Eds, Augustine and Politics (Oxford: Lexington Books, 2005), p.188).

${ }^{16}$ Augustine, On Genesis, transl. Edmund Hill, O.P. (New York: New City Press, 2002), 8.9.17.

${ }^{17}$ CG XII.22. p.533.
} 
ordered co-existence, orienting all things toward 'an ordered concord of civic obedience and rule in order to secure a kind of co-operation of men's wills for the sake of attaining the things which belong to this mortal life' ${ }^{18}$ Ensuring that law achieves this purpose requires constant vigilance because violence is at the core of earthly empire and no wishful thinking can erase this.

Amidst the realities of global politics of his day, Augustine lifts our eyes from the many and valid reasons for deep scepticism about what human law can achieve to the human vocation to politics and possibility that law can still function beneficially in the restoration, maintenance and furtherance of peace. The true meaning of order, like justice, eludes human knowledge yet a pattern may be discerned in Augustine's advocating of how the conditions for peaceable and ordered co-existence may be realized. Peace is referenced always to that which is greater than the immediate interests of a given individual, family or city:

A man's household, then, ought to be the beginning, or a little part, of the city: and every beginning has a reference to some end proper to itself, and every part has reference to the integrity of the whole of which it is a part. From this, it appears clearly enough that domestic peace has reference to civic peace: that is, that the ordered concord of domestic rule and obedience has reference to the ordered concord of civic rule and obedience. Thus, it is fitting that the father of a family should draw his own precepts from the law of the city, and rule his household in such a way that it is brought into harmony with the city's peace. ${ }^{19}$

The quality of peace varies. Even gangsters need some kind of peace in order to exploit ill-gotten gains: 'Even he (a robber - EDR) maintains some shadow of peace, at least with those whom he cannot kill, and from whom he wishes to conceal his deeds', from whence he would rise from his lair and raise himself up as a king if opportunity allowed..$^{20}$ Augustine's point, however, is that the violence of the state and its magistrates should be different to that of gangsters to the extent because it has a high threshold of necessity and is measured against the requirements of common good. The purpose of good law is peace, referenced always to the common or greater good.

\section{Biggar's Contextualism}

This brings us to Biggar's highly contextual approach to the United Nations Charter and the laws of war. Chapter 6 of In Defence of War is entitled: 'On not always giving the Devil the benefit of law' .... or, says Nigel, 'if not quite the Devil, then, as some

\footnotetext{
${ }^{18} C G$ XIX, 17, p.945.

${ }^{19} C G$ XIX, 17, p.945.

${ }^{20} C G$ XIX, 12, p.934.
} 
argued in relation to the Kosovo war in 1999, Slobodan Milošević (p.219). Nigel faces head-on the question of whether, in this instance, international treaty law, strictly prohibited what it should not (p.223). Few will dispute the notion that an unjust law is no law. ${ }^{21}$ But that's not quite the point at issue. Biggar asks not about laws that are unjust per se but about whether and/or when to override laws which prohibit action that might be deemed morally desirable, given political processes at the UN that might stymy action to authorize such action. Instances are given when the Charter's rule of non-intervention and absence of a doctrine of humanitarian intervention has been viewed widely as meaning that 'international treaty law, strictly read, prohibits what it should not' (p.223). In tracking debate between Ian Brownlie and Richard Lillich, the chapter frames a struggle between 'textualist' and 'contextualist' lawyers for the true meaning of international law. Biggar makes his own position clear with reference specifically to the controversy about Kosovo: 'I do not believe that the meaning of international law lies in texts as distinct from their context. What the UN Charter means must be understood in terms of the historical context of its origin' (p.227).

I accept with Biggar that account must be taken of context in any interpretation of (quasi-)legal principles and texts. The UN Charter was written in a particular historical-cultural context at a time when a particular complex of political and otherwise evaluative convictions contributed to its formation. As a matter of principle, I accept that there are instances when individuals and states might have to act outside the law. But to leave the matter here risks leaving the framing of international law to those with most to gain. Whether or not we agree that NATO's 1999 intervention in Kosovo was morally right, my concern is that Biggar's defence of war lacks equal consideration for the political processes whereby laws for the constraint of war and mitigation of its horrors are contested. Defence of war requires equal concern for defence of the legal regime governing the use of force by regional security organizations.

At issue is whether Biggar defence of war is matched by equal care for the laws of war. While Biggar's permissive reading of the classic, theological just war tradition yields several conclusions with which I am uncomfortable, this essay has attempted to draw attention to the inseparability of Augustine's questions about disordered

\footnotetext{
${ }^{21}$ Augustine, On Free Choice of the Will, Book 1, §5.
} 
political 'loves' from the more familiar questions of 'right cause', 'right authority' and 'right intention'. Reading Augustine reminds us that political 'loves' still determine not only decisions to engage in armed conflict but also international law as an instrument of influence for the dominant powers and/or a means of giving voice to the terrorized and vulnerable; a means of disseminating the values of the most powerful states and/or instrument for holding the most powerful to account. It is concerning that Biggar treats legal constraints on the use of military force under the 'Aunt Sally' heading 'The prospects of global government' (p.241), i.e., a quasiapocalyptic notion of a single common political authority for all humanity that is not a serious political option, thereby deflecting attention from the need for laws to restrain and regulate armed conflict, and failing adequately to expose the political 'loves' of great world powers in the determination of the laws of war.

2974 words excluding abstract. 